Dept. of Bacteriology,

Animal Health Research Institute, Assiut Lab.

\title{
ETIOLOGICAL STUDIES OF ENTERITIS IN COMMERCIAL RABBITS
}

(With 4 Tables and 12 Figures)

By

\section{AZHAR M. HASSAN; NEVEN A. EL-NISR*}

\section{and EMAN M.A. EL-NASER**}

* Dept. of Pathology, Animal Health Research Institute, Assiut Lab.

** Dept of Biochemistry and Nutritional Deficiency Diseases,

Animal Health Research Institute, Assiut Lab.

(Received at 17/8/2009)

\section{دراسات عن مسببات الاسهالات في الاراتب التجارية}

\section{ازهار محمد حسن ، نيفين عبل الغتسي النسر ، ابيان محمد عبل الثصر}

أجريت هذه الدراسة علي عدد 123 من الأرانب التي تنتراوح اعمار ها بين 1 الي ولي 3 شهور وكانت تعانى من الاسهال وحالات النزلة لاتلة

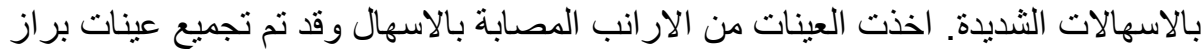

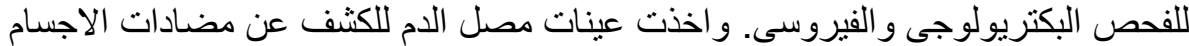

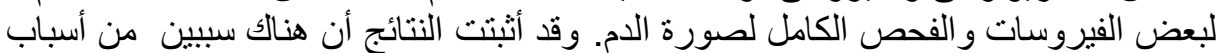

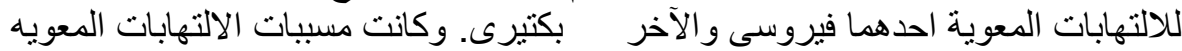

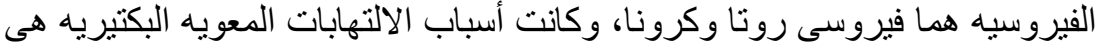

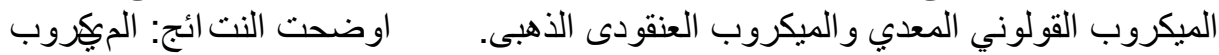

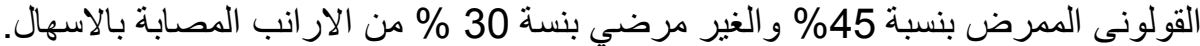

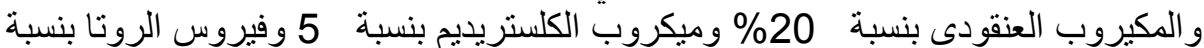

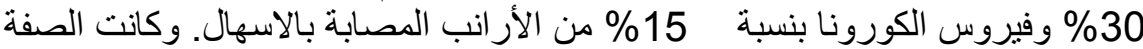

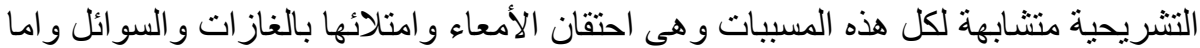

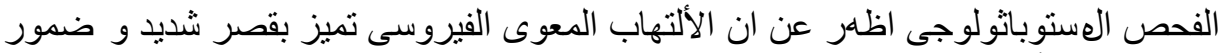

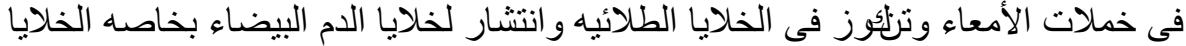

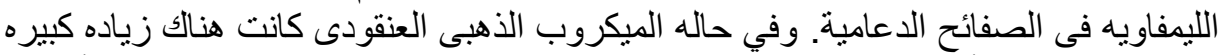

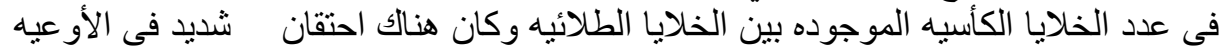

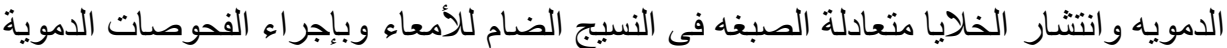

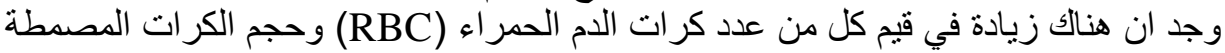

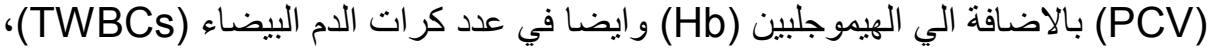

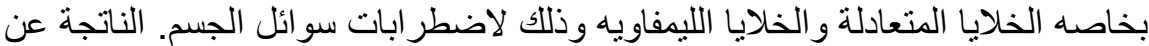
الاصابة بالاسهال و الالتهابات المعوية. 


\section{SUMMARY}

This study includes 123 rabbits aged from 1-3 months of both sex. Twenty rabbits were suffered from enteritis, and the others were found apparently clinically healthy and 8 rabbits were chosen to be the control group. These rabbits were used for determination of the causative agents of enteritis either bacterial or viral. These rabbits obtained from commercial farms. All rabbits were subjected to careful clinical and laboratory examination. Faecal samples were obtained directly from the rectum of each rabbit under aseptic conditions in sterile container, examined for bacteriological and virological tests for detection the causative agents of enteritis. Faecal examination showed the following Pathogenic and non -pathogenic organisms in respective order as follow: $45 \%$ pathogenic E. coli, $30 \%$ non-pathogenic E. coli, 5\% Clostridium piliform., 20\% Stapholoccus Spp, 30\% Rota virus and 15\% corona virus. The gross picture was similar in both bacterial and viral enteritis as the intestine was congested and filled with gasses and fluids. Microscopically the intestine in cases of viral enteritis showed short, atrophic villi and its epithelium was degenerated and necrosed. Also the lamina propria was infiltrated with lymphocytes. In case of $E$. coli and Clostridium piliform infection the intestine showed atrophic villi, degenerated epithelium and the lamina propria was edematous, congested and infiltrated with different leukocytes. In case of S. aureus infection the intestine showed increased number of goblet cell in the epithelium and neutrophilic cell infiltration in the lamina propria. There were a significant increase in the levels of erythrocytic counts (RBCs), packed cell volume (PCV), hemoglobin $(\mathrm{Hb})$, total leukocytic counts (TWBCs), neutrophils and lymphocytes and these were usually with cases of enteritis and loss of body fluids.

Key words: Rabbit, enteritis, causative agents.

\section{INTRODUCTION}

Enteritis is a term used to describe a disease in which diarrhea is a major clinical finding due to malabsorpation in the intestinal tract. There are many causes of enteritis or malabsorption in farm animals. Enteropathogenes including bacteria and viruses are common causes of enteritis (Jones and Duff, 2001).

Among the most common causes of intestinal diseases of microbial origin in developing countries are E. coli, toxins of $S$. aureus 
and Clostridium Sp. (Kumar et al., 1997). Members of the genus Rotavirus, in the Reoviridae and Corona virus, infect the gastrointestinal tract of most mammals and birds (Jubb et al., 1993). Calf hood Rota virus enteritis affects calves and antiginically related viruses cause diarrhea in lamb and rabbits (Sastry, 1999).

The symptoms of digestive problems or enteritis in rabbits are simple and constant. The first sign which last 1 to 3 days is generally not noticed. And manifested by decrease in food intake. After the $5^{\text {th }}$ day moderate diarrhea accompanied by skin dehydration is usually observed. It consists of small quantities of liquid feces which soil the hind quarters of the rabbit (Jones and Duff, 2001).

Although there are several studies on hematology of various domestic animals, few data are available about hematological values of farm rabbits, in healthy and diseased conditions, since little or no attention has been paid to rabbits reared for meat production (Archetti et al., 2008).

Consequently, the objectives of the present study are to isolate some of the microbial causes of rabbits enteritis, describe the pathological changes of the intestine, and to evaluate some hematological parameters.

\section{MATERIALS and METHODS}

\section{A- Animals:}

Twenty diarrheic rabbits aged from 1-3 months were used in this study.

\section{B- Sampling: \\ 1- Faecal samples:}

A total of twenty faecal samples were collected from diarrheic and apparently healthy rabbits. Each sample was divided into two parts. The first, used for bacteriological examination, was inoculated into nutrient broth followed by incubation. Plating was carried out on the selective media. The second part was transported in sterile containers in frozen state. Samples were thawed and thoroughly mixed and diluted with (1 gm to $10 \mathrm{ml}$ phosphate buffer solution $\mathrm{pH} 7.4$ ). The diluted faecal homogenate were centrifuged at a low speed approximately 3000 r.p.m. for 20 minutes. The supernatant fluids were collected in sterile screw capped vial, and then samples incubated with large amount of antibiotics 1000ug $\backslash \mathrm{ml}$ (penicillin and streptomycin) were added because feacal sample cotains huge amount of intestinal flora(pathogenic or non 
pathogenic), left at room temperature for $15 \mathrm{~min}$., then kept at $-20^{\circ} \mathrm{C}$ until use. $10 \%$ penicillin and $10 \%$ streptomycin were added left at room temperature for $15 \mathrm{~min}$., and then kept at $-20 \mathrm{C}^{\circ}$ until use.

\section{2- Blood serum samples:-}

Blood samples were collected using methods of Uko et al. (2000) by puncturing the jugular vein and allowing free flow of blood into labeled sterile universal bottles. Pooled samples from each animal was divided into two parts. The first part, about $10 \mathrm{ml}$ was collected over labeled sterile universal bottles containing EDTA. This was used to determine the hematological components (Rbcs, Hb, MHC, MCV) according to the method of Ajagbonna et al. (1999) and Uko et al. (2000). The second part, about $10 \mathrm{ml}$ was collected over labeled sterile sample bottles without anticoagulant. The obtained clear blood serum sample was used for virological examination (Spencer and Price 1997; Ajagbonna et al., 1999 and Uko et al., 2000).

\section{3-Tissue samples:-}

After slaughtering the diseased rabbits, samples were taken from the intestine for bacteriological examination. For pathological examination, samples were fixed in $10 \%$ neutral buffered formalin. After complete fixation the processing was done routinely. Serial sections of $4 \mu \mathrm{m}$ thickness were obtained and stained with hematoxylin and eosin (H \& E) according to Bancroft et al. (1996).

\section{C-Adopted methods:-}

\section{1-Bacteriological studies:}

\section{Isolation and identification of the micro-organism:}

Sterile loopful from samples (faecal, and intestine) was inoculated into a nutrient broth, incubated overnight at $37 \mathrm{C}^{\circ}$ for enrichment and enhancement of bacterial growth. Subcultures were streaked on nutrient agar, 5\% sheep blood agar and MacConkey bile salt media. After incubation, suspected colonies were described for their appearance, haemolytic activity and morphological characters. Smears from the colonies were stained with Gram stain and examined microscopically then divided according to staining, reaction, and shape and cell arrangement.

The isolates were identified biochemically according to Cruickshank et al. (1975).

\section{2-Virological studies:}

A- Dot Immunobinding Assay (Dot-ELSA): This test was applied on total faecal samples from rabbits for detection of viral antigen according to Sato et al. (1977). 


\section{B- Haemagglutination and haemagglution inhibition tests:-}

Virus suspension, normal saline solution Nacl $0.85 \%$, red blood cells, microtiter plate with U-shape bottomed wells, single and multichannel microtiter pipettes graduated from 50-200 $\mu 1$ and glassware such as conical flasks, Petri-dishes, centrifuge tubes and pipette 5-10 ml. Procedures: 1-prepration of $1 \%$ red blood cells:In abeaker $(25 \mathrm{ml})$ having $1.0 \mathrm{ml}$ of a sterile solution of $\mathrm{Na}$ citrate $(3.8 \%)$ add $10 \mathrm{ml}$ of whole blood which is drawn by a venous or cardiac puncture and thoroughly mixed. Centrifuge the uncoagulated blood at $1000 \mathrm{rpm}$ for 15 min and then discard the supernatant plasna fliud. Wash the packed red blood cells by adding five volum of $\mathrm{Nacl}$ on it, mix thoroughly then recentrifuge again. Dilute the packed cells to cell suspension to use in $\mathrm{HA}$ and $\mathrm{HI}$ test. Haemagglutination and haemagglution inhibition tests.

2- HA test proper:- In a microtitre plate dispense 50uL of virus suspension miz to form 1-2 dilution. From his well transfer 50uL to the second well, miz and repeat this step until well no. 11 and no. 12 as control. To all wells in the first row add $50 \mathrm{uL}$ of $1 \%$ washed R.B.Cs. Read the test resylt when the contol well showing button like shape of precipitated R.B.Cs. It is the highest dilution of virus suspension which causes complete agglutination of R.B. Csand represents heamagglutination unit (HAU) per 50uL.

3- HI test proper:- If one HAU is equal to 256, 4 HAU can be prepared by adding one part of original virus suspension to 43 part of saline solution get dilution 1: 64. The isolated virus can be identified by inhibiting reaction by using specific antiserum.

This test was carried out as described by Sato et al. (1977).

\section{C- Statistical analysis:}

Statistical analysis of the obtained data was done by means of computer statistical performance (Spsswin, 1995). Means, standard error and significant of variance were statistically achieved.

\section{RESULTS}

\section{Clinical findings in diarrheic rabbits:}

Majority of rabbits suffering from diarrhea were weak, lethargic and anorexic.

\section{Bacteriological isolation:}

Results revealed that 9 isolates $(45 \%)$ of pathogenic $E$ coli, 6 isolates $(30 \%)$ of non pathogenic E. coli, 2 isolates $(20 \%)$ of Staphylococcus aureus and one isolate (5\%) of Clostridium piliform 
(Table, 1). Some of the cases showed mixed infections from pathogenic and non pathogenic E coli.

\section{Virological isolation:}

The results of virological examination revealed that 6 strains (30\%) proved to be Rota virus and 3 strains (15\%) proved to be corona virus were obtained from diarrheic rabbits (Table, 2).

\section{Pathological results:}

In case of viral enteritis, the intestinal mucosa was congested and the intestine filled with gases and watery fluid Fig. $(1,2)$. Some area in the intestine was empty and the cecum was filled with gases and little fluid. Microscopically: The villi were short, atrophic and fused while the crypts were elongated Fig. (3, 4). The intestinal epithelium was degenerated and necrosed Fig. (5). Also our results showed that the lamina propria was infiltrated by inflammatory cells mainly lymphocyte Fig (6).

In case of bacterial enteritis (Enterotoxigenic E. coli alone or in combination with $\mathrm{Cl}$. Piliform): The main gross picture was congestion of the intestinal epithelium and the intestine was filled with fluid Fig. (7) Microscopically: The more apparent lesions were noticed in cases infected with E. coli. As the intestine showed villus atrophy with sever degeneration in the intestinal epithelium Fig (8). The lamina propria was infiltrated with leucocytes mainly neutrophil, plasma cells and some lymphocytes Fig. (9). The lamina propria in the affected rabbits was edematous and congested Fig. (10). In case of S. aureus infection the pathological lesions were mainly increase number of the goblet cells and epithelial degenerative and necrobiotic changes Fig. (11). The lamina propria was hyperemic edematous and leukocytic infiltration Fig. (12).

Hematological results: Were shown in Tables (3 and 4).

Table 1: Percentage of some bacterial agents causes enteritis in commercial rabbits.

\begin{tabular}{|c|c|}
\hline Bacterial causes & Percentage \% \\
\hline Pathogenic E coli & 45 \\
\hline Non path. E coli & 30 \\
\hline Staphylococcus Spp & 20 \\
\hline Clostridium pilli form & 5 \\
\hline
\end{tabular}


Table 2: Percentage of viral causes enteritis in commercial rabbits.

\begin{tabular}{|c|c|}
\hline $\begin{array}{c}\text { Causative } \\
\text { agents }\end{array}$ & Percentage \% \\
\hline Rota virus & $30 \%$ \\
\hline $\begin{array}{c}\text { Corona } \\
\text { virus }\end{array}$ & $15 \%$ \\
\hline
\end{tabular}

Table 3: Mean values of RBCs, PCV, Hb, MCV, MCH, and MCHC in healthy and diarrheic rabbits:

\begin{tabular}{|c|c|c|c|c|c|c|}
\hline $\begin{array}{c}\text { Clinical } \\
\text { status }\end{array}$ & $\begin{array}{c}\text { RBCs } \\
(\mathrm{T} / \mathrm{L})\end{array}$ & $\begin{array}{c}\text { PCV } \\
\text { Healthy rabbits }\end{array}$ & $\begin{array}{c}\mathrm{HB} \\
\mathrm{gL}\end{array}$ & $\begin{array}{c}\mathrm{MCV} \\
\mathrm{Fl}\end{array}$ & $\begin{array}{c}\mathrm{MCH} \\
\mathrm{Pg}\end{array}$ & $\begin{array}{c}\mathrm{MCHC} \\
\mathrm{g} / \mathrm{dl}\end{array}$ \\
\hline Diarrheic rabbits & $5.73 \pm 0.17$ & $29.04 \pm 0.58$ & $9.08 \pm 0.13$ & $59.3 \pm 1.1$ & $19.1 \pm 0.9$ & $31.3 \pm 0.3$ \\
\hline
\end{tabular}

Each value represents the means \pm standard errors, Significance compared to control: $\left\{{ }^{*} \mathrm{P}<0.05,{ }^{* *} \mathrm{P}<0.01\right\}$

Table 4: Mean values of total and differential leucocytic count of healthy and diseased rabbits: 
Assiut Vet. Med. J. Vol. 55 No. 123 October 2009

\begin{tabular}{|c|c|c|c|c|c|c|}
\hline $\begin{array}{c}\text { Clinical } \\
\text { Status }\end{array}$ & $\begin{array}{c}\text { TWBCs } \\
\text { GL }\end{array}$ & $\begin{array}{l}\text { Neutroph } \\
\text { il } \\
\%\end{array}$ & $\begin{array}{c}\text { Lymphocyt } \\
\%\end{array}$ & $\begin{array}{c}\text { Monocyt } \\
\%\end{array}$ & $\begin{array}{c}\text { Basophil } \\
\%\end{array}$ & $\begin{array}{l}\text { Eosonoph } \\
\text { il } \\
\%\end{array}$ \\
\hline $\begin{array}{c}\text { Healthy } \\
\text { rabbit }\end{array}$ & $7.17 \pm 0.2$ & $31.6 \pm 1.7$ & $60.2 \pm 1.6$ & $1.7 \pm 0.5$ & $1.1 \pm 0.2$ & $1.6 \pm 0.5$ \\
\hline $\begin{array}{c}\text { Diarreac } \\
\text { rabbits }\end{array}$ & $9.28 \pm 0.3^{* *}$ & $33.3 \pm 0.8^{* *}$ & $64.1 \pm 1.9^{* *}$ & $1.8 \pm 0.6$ & $0.8 \pm 0.3$ & $1.2 \pm 0.5$ \\
\hline
\end{tabular}

Each value represents the means \pm standard errors, Significance compared to control: $\left\{{ }^{*} \mathrm{P}<0.05,{ }^{* *} \mathrm{P}<0.01\right\}$ 
Assiut Vet. Med. J. Vol. 55 No. 123 October 2009

9 
Assiut Vet. Med. J. Vol. 55 No. 123 October 2009 
Assiut Vet. Med. J. Vol. 55 No. 123 October 2009 


\section{FIGURE LEGENDS}

Fig. 1: Showing intestine of rabbit with viral enteritis showed severe redness (congestion).

Fig. 2: Showing intestine of rabbit with viral enteritis and filled with fluid and gase.

Fig. 3: Showing intestine of rabbit with viral enteritis and showed villus atrophy (arrow) H\&E X25.

Fig. 4: Showing intestine of rabbit with viral enteritis and showed fusion of two villi H\&E X25.

Fig. 5: Showing intestine of rabbit with viral enteritis and the intestinal epithelium undergone extensive degeneration and karyorrhexis H\&E X25.

Fig. 6: Showing intestine of rabbit with viral enteritis showed leukocytic infiltration in the lamina propria, mainly lymphocyte (arrow) H\&E X25.

Fig. 7: Showing intestine of rabbit with bacterial enteritis filled with gases.

Fig. 8: Showing intestine of rabbit infected with E. coli and showed severe necrobiotic changes in the intestinal epithelium. H\&E X25.

Fig. 9: Showing intestine of rabbit infected with E. coli and showed cellular infiltration in the lamina propria (arrow) H\&E X10.

Fig. 10: Showing intestine of rabbit infected with E. coli and showed edema, congestion and hyperemia in the lamina propria (arrow) H\&E X10.

Fig. 11: Showing intestine of rabbit infected with S.aureus showed increase number of goblet cell (arrow). H\&E X10.

Fig. 12: Showing intestine of rabbit infected with S.aureus showed increased number of the goblet cell, cellular infiltration and edema of the lamina propria. H\&E X25.

\section{DISCUSSION}

The bacteria populations in a rabbit's intestinal tract are considered the most delicately balanced of any in all herbivorous mammals. The growth and activity of normal (favorable) bacteria tend to keep potentially harmful bacteria in check Digiacomo and Thouless (1984) and Fennested, (1985). Overgrowth of harmful bacteria usually results in production of toxins that are rapidly absorbed into the rabbit's 
circulation, quickly causing illness and death. In addition to orally administered antibiotics can disturb the balance of bacteria. Rapid changes in the diet are most often implicated. So to help their intestinal tracts, some powders should add to the drinking water as Lactobacillus or Acidophilus product, plus Tang (General foods) (Camguilhem and Milon, 1989).

Escherichia coli considered one of the causes of rabbit diarrhea (Enteropathogenic strain of E. coli). Normal healthy rabbits do not have any pathogenic strain of $E$. coli associated with their gastro-intestinal tract. Diarrhea was severe and yellowish in color. Intestines are filled with fluid, rough coat and perineal area covered with greenish brown faecal materials. The incidence of pathogenic $E$ coli was greatest under poor hygienic measures, poor husbandry and other stress factors. Other bacterial causes as Staphylococcus sp. and Clostridium accompanied by acute onset of profuse watery diarrhea, depression and dehydration. The obtained results were in agreement with those obtained by Camguilhem and Milon (1989). The total percentage of rota and corona viruses were 30 and $15 \%$ respectively, these result coincide with those revealed by Digiacomo and Thouless (1984) and Fennested, (1985). The highest percentage of infection with rota virus can be explained as a result of the nature of virus stability in the environment (Janke, 1989).

Grossly: The intestinal mucosa, in case of viral enteritis, was congested and the intestine was filled with gases and watery fluid, some area in the intestine was empty and the cecum was filled with gases and little fluid. During the acute phase of rabbit enteritis, the intestinal content is liquid and its aspect is congested (Hoop et al., 1993). Cecum appears congested (Kumar et al., 1997 and Kipar et al., 1998). The fluid and gases formation in cases of rotavirus and corona virus were attributed to their atropism for the absorptive lining cells (enterocytes) of the intestine result in destruction and malabsorption. The ingesta and normal alimentary secretion were fermented in the intestine by bacteria, increasing the osmolarity of the intestinal content with subsequent increase in the fluid content of the bowel (Carliton and Mc Gavin, 1995). Microscopically: The villi were short, atrophied and fused while the crypts were elongated, the intestinal epithelium was degenerated and necrosed and the lamina propria was infiltrated by inflammatory cells mainly lymphocyte. Viral enteritis mainly caused by rota virus and corona virus (Holland, 1990), the pathogenesis of both viruses is similar (Jubb et al., 1993) and characterized by sluphing of villus cells which followed by atrophy, blunting and fusion of villi (Burkitt et al., 1992 and 
Hoop et al., 1993). The affinity of corona and rota viruses to the absorptive lining cells of the intestine cause destruction of these cells, this mechanism result in loss of enterocytes and at least temporary villus atrophy. The virus firstly infect the villus epithelium of the small intestine and colon these epithelium under gone extensive degeneration and necrosis (Torres-Medina et al., 1985, Vankruining et al., 1987 and Mc Gavin et al., 2001). In cases of viral enteritis the lamina propria near the surface contains increased number of lymphocyte and plasma cells (Tzipori, 1985 and Jubb et al., 1993).

In case of bacterial enteritis (Enterotoxigenic E. coli alone or in combination with $\mathrm{Cl}$. Piliform). The intesten was congested and filled with fluid. Enterotoxigenic E. coli infection cause dilated, flaccid small intestine which filled with translucent fluid (Olson et al., 1984).

Microscopically: The more apparent lesions were noticed in cases infected with $E$. coli. As the intestine showed villus atrophy with sever degeneration in the intestinal epithelium and the lamina propria was congested, edematous and infiltrated with leucocytes mainly neutrophil, plasma cells and some lymphocytes. The same picture was documented by (Canty and Blake, 1977 and Law, 1988) who explain this villus atrophy in human, rabbits and lamb by the ability of $E$. coli to attach to the luminal aspect of enterocytes on villi throughout the small intestine resulting in exfoliation of the affected cells and mild to severe atrophy of the villi also local infiltration by neutrophil (Hollaned, 1990). Furthermore Carlton and McGavin (1995), founded that the villous atrophy occurs in the intestine was response to the heat stable enterotoxins B. which secreted from enterotoxigenic E. coli. The E. coli infection cause damage of the surface epithelium which followed by hyperemia, edema and variable neutrophilic infiltration in the lamina propria (Kumar et al., 1997). In cases of clostridial infection the main lesion was severe necrosis in the intestinal epithelium. Clostridium spp. Produce enterotoxins and cause epithelial damage (Kumar et al., 1997). In case of $S$. aureus infectio the pathological lesions were mainly increase number of the goblet cells with epithelial degenerative and necrobiotic changes, the lamina propria was hyperemic, edematous and leukocytic infiltration. S. aureus is one of the pathogens associated with infectious diarrhea, the ability of $S$. aureus to cause this lesions may be due to the presence of peptidoglycan (PGN) which is a cell wall component of S. aureus and has strong immune activity as it capable of modifying the functions of some immune cells (Bai Sui et al., 2007). Furthermore stated that oral antibiotic therapy may cause enteritis by 
alteration of the intestinal flora due to over growth of other bacteria as Staphylococci which are normally kept under restraint and enteritis results. The cases from which $S$. aureus isolated showed edema in the intestine due to exudates with leukocytes in the lamina propria, and the goblet cells were numerous that produced large amounts of mucin (Sastry, 1999).

In healthy rabbits, the mean values of erythrocytic counts (RBCs), Packed cell volume (PCV), Hemoglobin (Hb), mean corpuscular volume (MCV), Mean corpuscular hemoglobin $(\mathrm{MCH})$, Mean Corpuscular hemoglobin concentration (MCHC), total white blood cell counts (TWBCs) and differential leucocytic counts shown in (Tables 3 and 4) and these obtained data were found to be within the range reported by many authors for clinically healthy rabbits (Ajagbonna, et al., 1999 and Uko, et al., 2000).

The mean values of RBCs, PCV, Hb, MCV, MCH, MCHC, showed high significant increase in the enteric rabbits (Tables 3). Such elevations are usually associated with enteritis and attributed to excessive loss of body fluids, heamoconcentration and reduction of vascular space. Theses findings are in agreement with those previously obtained by (Ahamefule, et al., 2006 and Archetti, et al., 2008).

The mean values of total leucocytic counts, neutrophils, and lymphocytes showed high significant increase in the enteric rabbits, (Table, 4). These findings could be attributed to bacterial and virus infections and inflammatory lesions that act as stimuli for production of neutrophils and lymphocytes. Theses results agreed with those recorded by Holland, (1990) and Hoop et al. (1993).

\section{CONCLUSION}

Our result proved that, there were two causes of enteritis, viral enteritis and bacterial enteritis. The viral enteritis was caused by rota and corona virus while the bacterial enteritis was caused by E. coli and $S$. aureus

Pathologically: the intestine in both viral and bacterial enteritis was characterized by atrophy of the intestinal villi and necrobiotic changes in the intestinal epithelium, the lamina propria showed inflammatory cell infiltration. Mainly lymphocyte in case of viral enteritis and neutrophil cell in case of bacterial enteritis. The main heamatological indices of enteritis in rabbits were hemoconcentration (increase of RBCs, $\mathrm{Hb}$, and PCV). An increase in the total white blood cell counts (TWBCs), neutrophils and lymphocytes. 


\section{REFERENCES}

Ahamefule, F.O.; Eduok, G.O.; Usman, A.; Ahamefule, K.U.; Obua, B.E.; and Ogunike, S.A. (2006): Blood chemistry and haematology of weaner rabbits fed sun dried, ensiled and fermented cassava peel based diets. Pak. J. Nutr., 5: 248-253.

Ajagbonna, O.P.; Onifade, K.I. and Suleman, U. (1999): Haematological and biochemical changes in rats given extracts of Calotropis procera. Sokoto J. Vet. Sci., 1: 36-42.

Archetti, I.; Tittarelli, C.; Cerioli, M.; Brivio, R.; Grilli, G. and Lavazza, A. (2008): Serum chemistry and heamatology values in commercial rabbits: preliminary data from industrial farms in northern italy. $9^{\text {th }}$ world rabbit congress, 6: 10-13, Verona-Italy.

Bai-Sui Feng, Shao-Heng Peng-yuan He; Zheng, Lind Wu; and PingChang Yang (2007): Mast cells play a crucial role in S.aureus peptidoglycan induced diarrhea .Am. J. Pathol. 171: 537-547.

Bancroft, J.D.; Stevens, A. and Turner, D.R. (1996): Theory and practice of histological techniques $4^{\text {th }}$ Ed Churchill living stone, New York Edinburgh. Madrid, Sanfrancisco, Tokyo.

Burkitt, G.; Stevens, A.; and Lowe, J. (1992): Basic histopathology. A color atlas and text, second edition Churchill living stone, Robert Stevenson house, Edinburgh.

Camguilhem, R. and Milon (1989): Biotypes and Oserogroup of Escherichia coli involved in intestinal infections of weaned rabbits: Clues to diagnosis of pathogenic strains. J. Clinc. Microbial. 27: 743-747.

Canty, J.R. and Blake, R.K. (1977): Diarrhea due to Escherichia coli in the rabbit. A novel mechanism. J. Infect. Dis. 135: 454-462.

Carlton, W.W. and McGavin (1995): Thomson's special Vet. Pathology. $2^{\text {nd }}$ Ed. mosby. St. louis, Baltimore Boston. Chicago. Naples New York Philadelphia, 50-59.

Cruicckshank, R.; Duguid, J.P.; Marmion, B.P. and Swain, R.H.A. (1975): Medical microbiology. $12^{\text {th }}$ ed., Livingstone, London and New York.

Digiacomo, R.F. and Thouless, M.E. (1984): Aged- related antibodies to Rota virus in New Zealand rabbit. J. Clin. Microbial. 19: 710-711.

Fennestad, K.L. (1985): Pathogenetic observations on pleural effusion disease in rabbits. Arch. Virol. 84: 163-174. 
Holland, R.E. (1990): Some infectious causes of diarrhea in farm animals. Clin. Microbiol. Rev. 3: 345-375.

Hoop, R.K.; Ehrsam, H. and Keller, B. (1993): 10 years of rabbit autopsy-a review of frequent disease and mortality causes. Schweiz Arch. Tierheilkd, 135: 212-216.

Janke, B.H. (1989): Protecting calves from viral diarrhea. Symposium on Neonatal Calf Diarrhea. Vet. Med., 803-810.

Jones, J.R. and Duff, J.P. (2001): Rabbit epizootic enterocolitis. Vet. Rec. 149: 532-539.

Jubb, K.V.F.; Kennedy, P.C. and Palmer, N. (1993): Pathology of domestic animals fourth edition, Academic press INC. Harcourt brace. Jovanovich Publishers.

Kipar, A.; Kremednah, J.; Addie, D.D. and Reinacher, M. (1998): Fatal enteritis associated with corona virus infection in cats. J. Comp. Pathol. 119: 1-14.

Kumar, Vinay; Cotran; Ramzi, S. and Robbins, Stanley, L. (1997): Basic pathology $6^{\text {th }}$ Ed. W.B saunders company. Philadelphia, London, Toronto, Montreal, Sydney and Tokyo. 493-495.

Law, D.V. (1988): Virulence: factors of enteropathogenic E coli. J. Mol. Microbial 26: 1-10.

Mc Gavin, M.D.; Carlton, W.W.; and Zachary, J.F. (2001): Thomson's special veterinary pathology: $3^{\text {rd }}$ Ed. Mosby A Harcourt Health Sciences Company. St. London, Philadelphia, Sydney. Toronto. 40-50.

Olson, P.; Hedhammer, A. and Wadstrom, T. (1984): Enterotoxigenic Escherichia coli infection in two dogs with acute diarrhea. J. Am. Vet. Med. Assoc. 184: 982-983.

Sastry, G.A. (1999): Vet. Pathology, $6^{\text {th }}$ Ed. CBS Publisher and distributor. Newdelhy, India. 354-356.

Sato, K.; Inaba, Y.; Kurog, H.; Takahash, E.; Gato, Y.; Omari, T. and Matumoto, M. (1977): Physico-chemical properties of calf diarrhea Corona virus. Vet. Microbiol. 2, 73-75.

Spencer, K. and Price, C.P. (1997): Chemical analysis of bilirubin in biological fluids. Annal of clinical biochemistry, 14: 105-115.

Spesswin (1995): Software packet for statistical analysis under windows, U.S.A.

Torres-Medina, A.; Scfer, D.H. and Mebus, C.A. (1985): Rota viral and Corona viral diarrhea. Vet. Clin. North. Am. Food, Animal, Pract 1: 471-493. 
Tzipori, S. (1985): The relative importance of enteric pathogens affecting neonates of domestic animals. Adv. Vet. Sci. Comp. Med. 29: 103-206.

Uko, O.J.; Ataja, A.M. and Tanko, H.B. (2000): Weight gain, haematology and blood chemistry of rabbits fed cereal offal. Sokoto J. Vet. Sci., 2: 18-26.

VanKruining, H.J.; Khairalla, L.H.; Sasserville, V.G. and Post, J.E. (1987): Calf hood Cronavirus enterocolities. A clue to the etiology of winter dysentery. Vet. Pathol. 24: 564-567. 
Assiut Vet. Med. J. Vol. 55 No. 123 October 2009

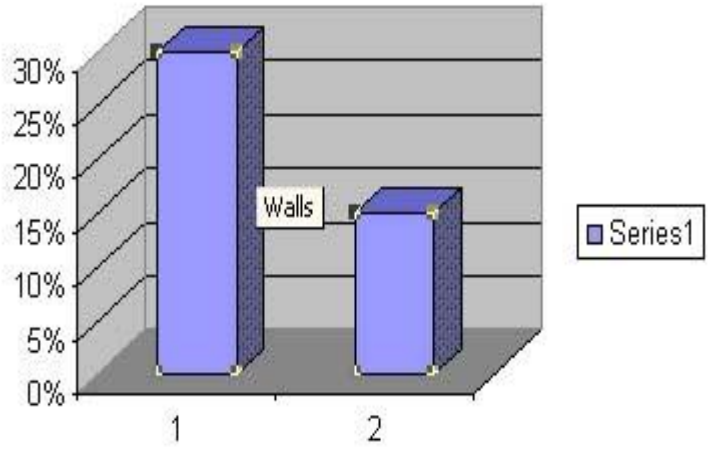

